\title{
Advances in biomarker for stroke patients: from marker to regulator
}

\author{
Oh Young Bang ${ }^{1,2}$ \\ ${ }^{1}$ Department of Neurology, Samsung Medical Center, Sungkyunkwan University School of Medicine, Seoul, Korea \\ ${ }^{2}$ Translational and Stem Cell Research Laboratory on Stroke, Samsung Medical Center, Seoul, Korea
}

Received: January 16, 2017

Revised: February 26, 2017

Accepted: February 27, 2017

Corresponding author:

Oh Young Bang

Department of Neurology,

Samsung Medical Center,

Sungkyunkwan University

School of Medicine, 81 Irwon-ro,

Gangnam-gu, Seoul 06351, Korea

Tel: +82-2-3410-3599

E-mail: ohyoung.bang@samsung. com

\begin{abstract}
Biomarkers refer to indicators found in the blood, other body fluids or tissues that predict physiologic or disease states, increased disease risk, or pharmacologic responses to a therapeutic intervention. Stroke is a heterogeneous condition, and stroke biomarkers could be used as a guiding tool for more effective personalized therapy. In this review, the recent advances in the biomarkers in stroke field are discussed. First, various types of biomarkers including genetic, extracellular vesicle, and metabolomics-associated biomarkers as well as protein biomarkers were recently introduced. The studies reviewed herein suggest that comprehensive analysis of different types of stroke biomarkers will improve the understanding of individual pathophysiologies and further promote the development of screening tool of high-risk patients, predicting model of stroke outcome and rational stroke therapy tailored to the characteristics of each case. Second, several biomarkers can be bio-'makers' that regulate compensatory or pathological process in the development of stroke etiology and recovery after stroke. Several protein (e.g., chemokines, caveoli), genetic (e.g., microRNA), and extracellular vesicles (e.g., cancer cell, stem cells-derived) may be directly involved in these processes. These bio-makers may be molecular target of treatment and can be used for new drug development.
\end{abstract}

Keywords: Biomarkers; Precision medicine; Risk factors; Stroke, ischemic; Therapeutics
This is an Open Access article distributed under the terms of the Creative Commons Attribution Non-Commercial License (http:// creativecommons.org/licenses/ by-nc/4.0/).

\section{INTRODUCTION}

Precision medicine relies on biomarkers with which to better classify patients with their disease risk, prognosis, and treatment response. In a narrow sense, biomarkers refer to indicators measured by chemical or biologic tests using blood or urine that predicts physiologic or disease states, or increased disease risk. Biomarkers are also a valuable tool in drug development providing more accurate and complete information regarding drug performance, disease progression, or response to a specific drug therapy. Treatment according to the biomarkers has also been investigated in various diseases including ischemic heart disease, cancer, or immunological disorders. On the contrary, there has been relatively lack of biomarker researches in cerebrovascular disease.

The importance of considering heterogeneity among stroke patients has emerged. Unlike 
coronary heart disease, stroke has heterogeneous pathophysiologies and mechanisms. Moreover, individual patients with stroke have different features even among subjects with same stroke mechanisms. These aspects enhance the need for development of personalized medicine based on characteristics of each patient rather than performing large randomized clinical trials.

Herein, we review the current and new stroke biomarkers with their strengths and weaknesses focusing on the importance of comprehensive approaches and the role of biomarkers on the development of new drugs for stroke.

\section{ROLE OF BIOMARKERS IN STROKE RESEARCH}

\section{Screening high-risk subjects}

Although many attempts including national publicity and various programs for health promotion have been made to manage stroke risk factors, the prevalence of stroke has not been markedly reduced. This may be partially resulted from hidden risk factors of stroke. Interestingly, certain regions in the United States (stroke belt and buckle) have an unusually high incidence and mortality of stroke and the phenomenon could not be explained by the differences of the conventional risk factors [1,2]. Therefore, many researchers have devoted themselves to find nontraditional risk factors of stroke to explain it and numerous possible contributing factors have been identified, including metabolic syndrome, sleep-related breathing disorders, and air pollution [3,4].

In addition to these nontraditional risk factors, a series of biomarkers reflecting inflammation, hemostasis, thrombosis, endothelial function, or neurohormonal activity have been evaluated as potential tools in an effort to improve risk prediction of future stroke, and thereby avert future events [5-12]. Our recent biomarker study showed that although traditional risk factors have been reported to be different between cerebral microangiopathy and macroangiopathy, endothelial dysfunction and related renal dysfunction were associated with both types of cerebral angiopathies [13]. In the near future, genome-wide association study may also greatly contribute to build risk stratification models by identifying genetic variants that confer susceptibility to cerebrovascular disease [14].

\section{Rapid stroke diagnosis}

Although the diagnosis of acute stroke mostly relies on neuroimaging techniques, the evaluation of biomarkers of tissue injury would be an alternative strategy for rapid stroke assessment, especially for pre-hospital screening, and fast-tracking in emergency room. A rapid diagnosis of stroke based on biomarkers may be useful especially for pre-hospital screening, facilitating entry into fast track care pathway, and ancillary data when contemplating thrombolysis. However, a widely available, rapid, and sensitive diagnostic test for acute cerebral ischemia has not been available until now.

Recently, a biomarker panel rather than a single marker in isolation has been increasingly used to improve the diagnostic accuracy of suspected stroke. For instance, a diagnostic panel incorporating the levels of matrix metalloproteinase 9 (MMP-9), B-type natriuretic peptide, D-dimer, and S100 $\beta$ into a composite score enhanced sensitivity of early noncontrast computed tomography (CT) alone for acute stroke, although the diagnostic accuracy was clearly imperfect [15]. Furthermore, the approach was feasible as a point-of-care test in the emergency setting [15]. As the number of presumed biomarkers for stroke expands at an exponential rate, it would be expected to develop improved biomarker combinations for more accurate diagnosis of stroke.

\section{Detecting of possible stroke etiology and mecha- nisms of ischemic injury}

Several studies have focused on the use of biomarkers for detecting of possible stroke mechanisms. In addition, the molecular markers related to neuronal death can provide the information about the presence of tissue at risk of infarction $[16,17]$.

\section{Predicting drug response and outcome}

It has been well known that different patients respond in different fashions to the same medication. Among many factors that influence the effects of drugs, it is estimated that genetic factor can account for $20 \%$ to $95 \%$ of variability in drug disposition and effects [18]. For example, previous studies revealed that CYP2C9 and VKORC1 genetic variants are associated with warfarin dose requirement and clinical outcomes $[19,20]$.

Besides pharmacogenetics, several biomarkers are also contributing to the predicting drug response in patients with stroke, particularly when thrombolysis is administered. Specifically, elevated S100 $\beta$ and MMP-9 which were reported as serum markers of blood-brain barrier dysfunction before thrombolysis could predict hemorrhagic transformation after thrombolysis [21-23]; whereas, baseline levels of $\alpha_{2}$-antiplasmin were predictive of recanalization in patients treated 


\section{PRECISION AND FUTURE MIEDICINE}

Biomarkers of stroke

Table 1. Emerging roles of stroke biomarkers

\begin{tabular}{|c|c|}
\hline Role & Example of biomarkers \\
\hline $\begin{array}{l}\text { Screening high-risk (asymptomatic) } \\
\text { subjects }\end{array}$ & $\begin{array}{l}\text { CRP, fibrinogen, and inflammatory cytokines, vWF, BNP, and UACR for stroke risk [5-8,10-12] } \\
\text { ADMA for silent brain infarcts on MRI [9] } \\
\text { Genome-wide association studies of stroke [14] }\end{array}$ \\
\hline Rapid stroke diagnosis & $\begin{array}{l}\text { Protein biomarkers associated with glial and neuronal cells (S100ß, GFAP, NSE, MBP), inflammation (CRP, } \\
\text { MMP-9, VCAM, TNF- } \alpha \text {, IL-6, VEGF), thrombosis (VWF, D-dimer), and others (BNP, homocysteine) [15,26-28] }\end{array}$ \\
\hline $\begin{array}{l}\text { Detection of stroke mechanisms } \\
\text { and molecular-targeted treatment }\end{array}$ & $\begin{array}{l}\text { Mechanisms of neuronal death, e.g. glutamate, GABA [16,17] } \\
\text { Etiologic diagnosis of ischemic stroke, e.g., atherosclerotic (inflammatory markers) vs. cardioembolic (free } \\
\text { fatty acid or vWF) vs. cancer-coagulopathy (D-dimer) [29-33] }\end{array}$ \\
\hline Predicting drug response & $\begin{array}{l}\text { Pharmacogenomics for the resistance to antiplatelet agents, warfarin, statin, or thrombolysis } \\
\alpha_{2} \text {-Antiplasmin for recanalization after thrombolysis [24] } \\
\text { MMP-9 and S100 } \beta \text { for a high risk of hemorrhagic transformation after thrombolysis [21-23] } \\
\text { S100 } \beta \text { for delayed infarct expansion }[34,35]\end{array}$ \\
\hline Predicting outcome & $\begin{array}{l}\text { Inflammatory markers for early neurological worsening [36] and poor outcome after stroke [37] } \\
\text { D-dimer for early recurrent ischemic lesion [38] } \\
\text { Fibrin-monomer for thrombus formation in the left atrial appendage [39] } \\
\text { vWF for adverse events or vascular events in A-fib patients receiving warfarin [40] or aspirin [41] } \\
\text { BNP for functional outcome after A-fib stroke [42] } \\
\text { BDNF polymorphism for outcome after traumatic brain injury or subarachnoid hemorrhage [43,44] } \\
\text { Endothelial EV for predicting future cardiovascular events }\end{array}$ \\
\hline $\begin{array}{l}\text { Use as surrogate endpoints in } \\
\text { clinical trials }\end{array}$ & $\begin{array}{l}\text { Troponin T, CRP, BNP [45] } \\
\text { S100ß, nitric oxide for phase III trials }\end{array}$ \\
\hline $\begin{array}{l}\text { Use as new drug development } \\
\text { (theranostics) }\end{array}$ & $\begin{array}{l}\text { Chemokines (such as SDF-1 } \alpha \text { ) to improve recovery after stroke [25] } \\
\text { Caveolin to improve angiogenesis } \\
\text { MicroRNA to improve recovery after stroke } \\
\text { Cancer cell-derived EV for coagulopathy and stem cells-derived EV for stroke recovery }\end{array}$ \\
\hline
\end{tabular}

CRP, C-reactive protein; VWF, von Willebrand factor; BNP, B-type natriuretic peptide; UACR, urinary albumin/creatinine ratio; ADMA, asymmetrical dimethylarginine; MRI, magnetic resonance imaging; GFAP, glial fibrillary acidic protein; NSE, euron-specific enolase; MBP, myelin basic protein; MMP-9, matrix metalloproteinase-9; VCAM, vascular cell adhesion molecule; TNF- $\alpha$, tumor necrosis factor- $\alpha$; IL-6, interleukin 6 ; VEGF, vascular endothelial growth factor; GABA, $\gamma$-aminobutyric acid; A-fib, atrial fibrillation; BDNF, brain-derived neurotrophic factor; EV, extracellular vesicle; SDF-1 $\alpha$, stromal cell-derived factor $1 a$.

with thrombolysis [24]. There have been accumulating evidences that a number of biomarkers can predict clinical or radiological outcomes from cerebral ischemic events (Table 1) $[5-12,14-17,21-45]$.

\section{TYPE OF BIOMARKERS IN STROKE RESEARCH}

Stroke biomarkers include protein, genetic, extracellular vesicle (EV), and metabolomics-associated biomarkers. Each biomarker has different aspects, and its own advantages and drawbacks (Table 2). A recent study reported that multiple EV biomarkers in addition to existing protein biomarkers are valuable for predicting future cardio- and cerebrovascular events [46]. Therefore, comprehensive approach using a variety of biomarkers is warranted to overcome the limitations. In addition, multidisciplinary approaches including neuroim- aging biomarkers are needed.

\section{Protein biomarkers}

Researches using protein biomarkers in patients with ischemic cerebrovascular disease have mainly focused on pathophysiology, diagnosis, prognostication, and neuronal death in stroke [47]. A typical example of protein biomarkers is C-reactive protein $[7,48,49]$. However, a recent study raised the possibility that the relation may result from various biases [50]. Moreover, it has become skeptical about efficacy of biomarkers to predict stroke risk because they provide only limited additional information compared to the well-known stroke risk factors [51,52]. Further studies with more systematic approach and analysis are needed in this area.

\section{Genetic biomarkers}

Many epidemiological studies suggested that stroke has ge- 
Table 2. Strengths and weaknesses of various biomarkers

\begin{tabular}{|c|c|c|}
\hline Type & Advantage & Disadvantage \\
\hline Protein & $\begin{array}{l}\text { Post-stroke analysis } \\
\text { Gene-environment interaction } \\
\text { Quantitation }\end{array}$ & $\begin{array}{l}\text { Time-dependent and need for serial tests } \\
\text { Small numbers of final products (not causative in most) }\end{array}$ \\
\hline Gene & $\begin{array}{l}\text { Pre-stroke analysis } \\
\text { Automatism } \\
\text { Plentiful candidate } \\
\text { Possible role of pharmacogenomics on drug effectiveness } \\
\text { and toxicity }\end{array}$ & $\begin{array}{l}\text { Influence of environment (>gene) on the development of most } \\
\text { disease (polygenic) } \\
\text { Clinical usefulness of genetic risk factor is low } \\
\text { Stroke subtype-specific }\end{array}$ \\
\hline MicroRNAs & $\begin{array}{l}\text { Both pre- and post-stroke analysis } \\
\text { Stably expressed in circulation for several months after stroke } \\
\text { onset. } \\
\text { Functional and causative }\end{array}$ & $\begin{array}{l}\text { One microRNA has multiple gene targets, and need to } \\
\text { examine the combinatorial effect of multiple microRNAs } \\
\text { The sample size was usually limited, studies with larger patient } \\
\text { cohorts are needed }\end{array}$ \\
\hline Metabolomics & $\begin{array}{l}\text { Relatively plentiful candidate } \\
\text { Monitoring of treatment effects } \\
\text { May be functional }\end{array}$ & $\begin{array}{l}\text { Effortful and assay not readily available } \\
\text { Difficult to interpret the results (absence of clear cutoff of dis- } \\
\text { ease/normal state and intuitive connection between identified } \\
\text { species and disease state) } \\
\text { Studies in stroke field is relatively lacked }\end{array}$ \\
\hline
\end{tabular}

netic susceptibility, and various genetic factors were investigated [53]. However, genome-wide association studies failed to reproduce the positive results obtained from previous studies [54] or the clinical usefulness was very low [55]. For example, the hazard ratio and population attributable risk of hypertension to ischemic stroke is 2.0 and $26 \%$, respectively. Conversely, the genetic influence on stroke was only 1.3 to 1.33 and $11 \%$ to $12 \%$, respectively [55]. Genetic risk factors seem to be subtype-sensitive, and differential genetic risk factors have been reported to atherosclerotic, cardioembolic, and lacunar stroke [56]. Further stroke genetic studies might result in better risk prediction for different stroke subtypes and recurrent events, although conflicting result exists [57].

Recently, studies in pharmacogenomic area have been actively carried out. Among them, aspirin, clopidogrel, warfarin, statin, and thrombolytics-related genetic polymorphisms are particularly of interest. It is expected that selecting the type or dose of medication or avoiding side effects or drug resistance may be guided by simple genetic tests in the near future.

\section{Metabolomics}

The assumption of metabolomics is that occurrence of the disease is directly related to the specific change of biochemical composition in the cell or biological fluid. Metabolomics-associated biomarker research analyzes profiles of fatty acid, amino acid, or polyamine in the blood or urine and determines normal or pathologic states. Furthermore, metabolomics-associated biomarkers can be applied to the monitoring recovery after treatment. Unfortunately, studies using metabolomics in the area of stroke is relatively lacked.

\section{THERANOSTICS AND BIO-MAKER FOR THE DEVELOPMENT OF NEW DRUGS FOR STROKE}

Theranostic nanoparticles that simultaneously deliver both imaging and therapeutic agents have gained significant attention for disease management in recent years. Theranostic agents are able to simultaneously deliver imaging agent and therapeutic drugs. Recent advances in nanomedicine offers new tool for theranostics, several studies using nanoparticles have been applied in stroke animal models. For example, ceria nanoparticles and HSP72-vectorized immunoliposome to protect against ischemic stroke, and fibrin-targeted gold nanoparticles to direct imaging of cerebral thromboemboli 
on CT scan [58-60]. However, no theranostic drug have been approved by U.S. Food and Drug Administration for safety concerns.

Innate bioactive biomarker molecules may have pharmacological functions ("bio-maker") and can be used in stroke patients. While nanomedicine-based theranostics provides artificial membrane/compounds, these natural components may role as "safe tools" for theranostics. Therefore, identification and utilization of biomarkers is vitally important for the successful development of disease modifying drugs for diseases. There have been efforts for screening candidates for new treatment strategy among biomarkers to provide a tool for new drug development for stroke. Biochemical products arising from biosynthesis of materials could protect against ischemic injury and recovery after stroke (not from breakdown of brain tissue). Several proteins (e.g., chemokines), genetic (e.g., microRNA), and EVs could be the candidates for bio-maker that regulate compensatory or pathological process in stroke. In addition, several biomarkers (e.g., serum albumin) are related to stroke outcomes and may have a role as natural antioxidants in human. Table 3 shows essential features and examples for natural bio-makers in stroke field.

\section{Natural antioxidants}

Albumin is the most prominent protein in serum and a naturally existing antioxidant. In rat model, high-dose albumin has protective effects by reduction of the volumes of brain infarction/swelling and improvement of local perfusion to zones of critical blood flow reduction [61]. Beside albumin, bilirubin, and uric acid have been suggested to have a role as natural antioxidants in the body. Decreased levels of albumin and bilirubin were associated with poor outcome and exogenous application of albumin and uric acid may be beneficial in a certain subgroup of stroke patients (Table 4) [62-70].

\section{MicroRNAs}

MicroRNAs are short non-coding RNAs (18-23 nucleotide). MicroRNAs regress target gene expression by mRNA degradation and translation inhibition. Dysregulation of microRNAs has been linked to variety of disease development. Since many

Table 3. Essential features and examples of bio-makers for stroke

\begin{tabular}{lll}
\hline Aspect & \multicolumn{1}{c}{ Essential feature } & \multicolumn{1}{c}{ Example } \\
\hline Roles & $\begin{array}{c}\text { Diagnosis (biomarker)+Therapeutics (pharmacologic } \\
\text { effects) }\end{array}$ & $\begin{array}{l}\text { Hypoalbuminemia predicts further stroke, and application of } \\
\text { albumin reduces infarct size }\end{array}$ \\
Source & Naturally exist in human body & $\begin{array}{l}\text { Protein (e.g., albumin, chemokines) } \\
\text { RNAs (e.g., microRNAs) } \\
\text { EVs (e.g., stem cell-derived) }\end{array}$ \\
Molecules & $\begin{array}{l}\text { Increase by compensatory/rescue mechanisms } \\
\text { Decrease by pathophysiologic mechanism }\end{array}$ & $\begin{array}{l}\text { MicroRNA related to recovery/protection } \\
\text { Feasibility }\end{array}$ \\
\hline
\end{tabular}

EV, extracellular vesicle.

Table 4. Natural antioxidant in the body

\begin{tabular}{|c|c|c|c|}
\hline & Albumin & Bilirubin & Uric acid \\
\hline Blood levels & Related to renal loss of albumin & $\begin{array}{l}\text { Reflect intensity of oxidative } \\
\text { stress }\end{array}$ & $\begin{array}{l}\text { Decrease with oxidative stress (con- } \\
\text { sumptive?) [62] }\end{array}$ \\
\hline Low level & Poor outcome & $\begin{array}{l}\text { Poor outcome [63] } \\
\text { Increased incidence [64] }\end{array}$ & Controversial \\
\hline High level & Not associated & Decreased incidence [65] & Not associated \\
\hline $\begin{array}{l}\text { Clinical trials of exogenous } \\
\text { application }\end{array}$ & $\begin{array}{l}\text { Success in a small trial (especially in } \\
\text { recanalized patients) [66] but failed } \\
\text { in a multicenter RCT (ALIAS trial) [67] }\end{array}$ & Not done & $\begin{array}{l}\text { Failed in a RCT (URICO-ICTUS trial) } \\
\text { [68] but improved outcome in } \\
\text { selected patients (women or } \\
\text { recanalized patients) }[69,70]\end{array}$ \\
\hline
\end{tabular}

RCT, randomized clinical trial; ALIAS, albumin treatment for acute ischaemic stroke; URICO-ICTUS, efficacy study of combined treatment with uric acid and $r$-tPA in acute ischemic stroke. 
cell types express a set of microRNAs, microRNA signatures in circulation appear to be tissue-specific, representing their original source. Detectable levels of microRNAs exist in serum with tremendous stability, and circulating microRNAs in the serum can provide a novel class of biomarkers in cancer and other diseases [71]. In stroke field, increased or decreased levels of several circulating microRNA were reported in ischemic stroke patients [72,73]. For example, microRNA-424 level was decreased in acute stroke patients and in an animal model of stroke, and intracerebroventricular injection of lentiviral microRNA-424 reduced ischemic brain injury [72]. On the contrary, post-stroke increase in microRNA-200c contributed to ischemic brain injury by inhibiting reelin expression and inhibition of microRNA-200c resulted in an increase in cell survival [74]. There have been efforts of inhibition and overexpression of microRNAs to attenuate pathologic responses in cardiovascular disease, such as microRNA modulation using antagoMiRs (synthetic reverse compliments of oligonucleotides) that bind and silence target microRNAs or by using microRNA mimicry/pre-microRNAs that perform similarly to endogenous microRNAs [75]. Therefore, microRNAs serve as biomarker for stroke diagnosis and outcomes and also as stroke therapies.

\section{Extracellular vesicles}

EVs are defined as a heterogeneous population of small vesicles with a diameter of 0.1 to $1 \mu \mathrm{m}$. EVs may be a window for target cell/organs, and include genetic information (i.e., microRNAs) as well as protein inside them [76]. Moreover, it has been identified that EVs have their own function, revealing that EVs from ischemic tissue facilitated vasculogenesis in the ischemic limb model [77]. In this regard, biomarker research using EVs is a prominent field.

Nevertheless, biomarker studies using EVs in stroke are mostly performed in small cohorts. As the methods for analyzing EVs are complicated and not unique mainly due to their very small size, investigations with EVs are currently at a rudimentary state of development. When seeing the results from a large-scale clinical study for prediction of future risk of myocardial infarction, EVs could be a good candidate to compensate limitations of existing biomarker researches [46].

EVs play a critical role in the exchange of information between cells (Fig. 1). For example, stem cell-derived EVs alter the behavior of the target (damaged) cells. In recent studies, EVs secreted from mesenchymal stem cells (MSCs) promoted sciatic nerve regeneration in rats [78]. On the contrary, astrocytes release exosomes enriched in heat shock proteins and synapsin I under stress conditions [79]. Along with others, we

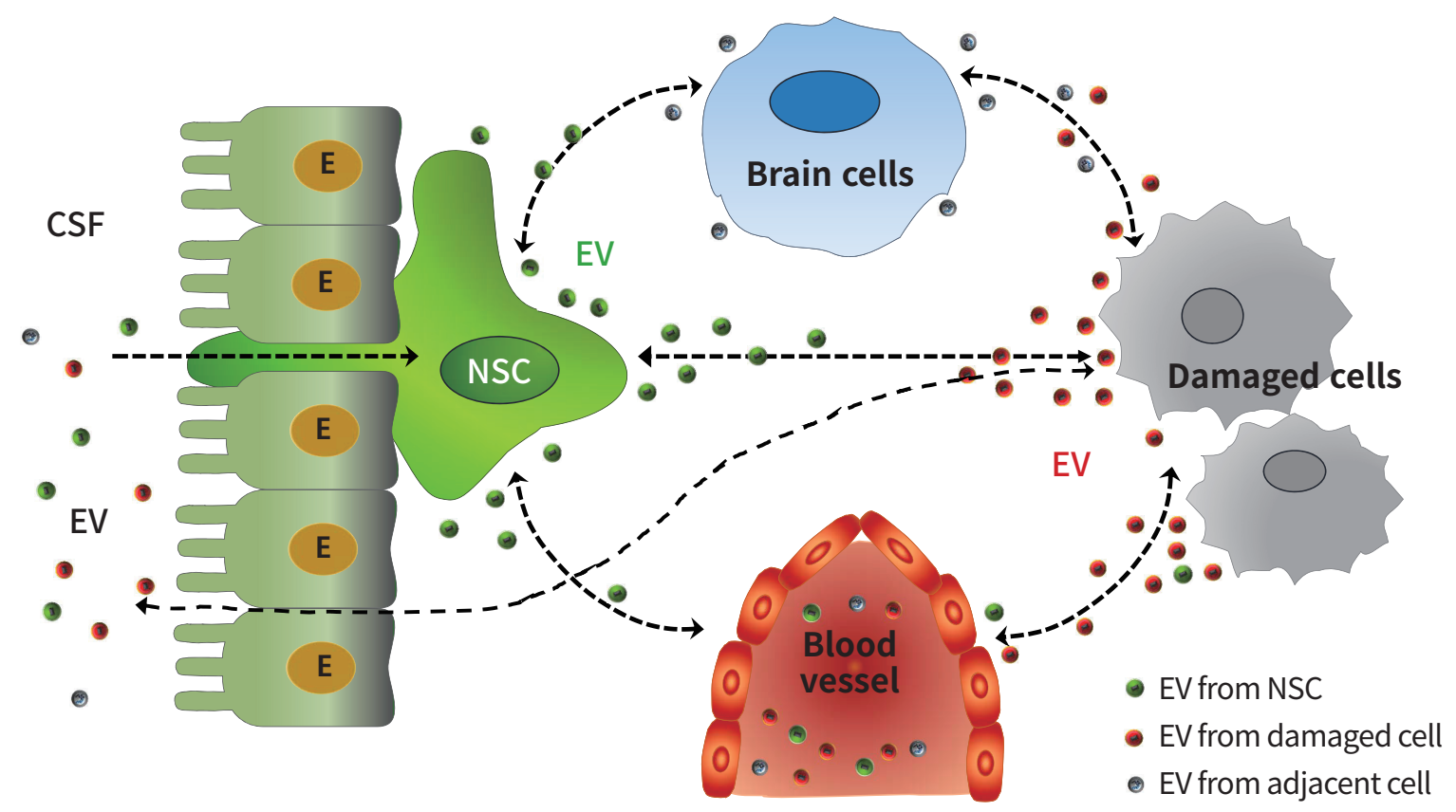

Fig. 1. Diagram outlining inter-cellular communications of extracellular vesicles (EVs) between neurogenic niche and damage cells. EVs released from neural progenitor/stem cells (NSCs) to extracellular milieu promote neuroprotection and neurorestoration after stroke. EVs contain genetic materials, protein and lipid and migration of EVs in the blood vessel and cerebrospinal fluid (CSF) provide the window for tissue in stroke patients. 
have shown that intravenous administration of EVs derived from MSC culture media promotes functional recovery and neurovascular plasticity after stroke in rats $[80,81]$. No studies have examined the effects of stem cell-derived EVs in stroke patients, but a phase 1 study of cord blood-derived MSC EVs in diabetes patients is ongoing (Clinical trial identifier NCT02138331).

\section{Others}

\section{Caveolin}

Caveolae are 50- to $100-\mathrm{nm}$ cell surface plasma membrane invaginations that are abundant in endothelial cells and play a major role in the regulation of endothelial vesicular trafficking and signal transduction [82]. Our recent study showed that the serum level of caveolin-1 is decreased in patients with moyamoya disease [83]. Caveolin could be a candidate of a stroke therapy as well as a stroke biomarker. Caveolin-1 is reportedly involved in the pathogenesis of cancers and vascular diseases [82]. Caveolin-1 expression was critical for vascular endothelial growth factor-induced angiogenesis [84] and recruitment of endothelial progenitor cells from the bone marrow [85]. Caveolin expression could be modulated by genetic regulation targeting caveolin-1 using antisense/small interfering RNA or microRNA, anti-caveolin-1 antibodies, and viral vectors or polymer that target the caveolae.

\section{Chemokines}

Our previous results have shown that serum level of chemokine (stromal cell-derived factor $1 \alpha$ [SDF-1a]) influences the effects of neurorestorative therapies in stroke patients [86]. The levels of chemokines increase markedly in the infarcted brain during the acute phase of stroke, but decrease over time. Increase the level of SDF-1 $\alpha$ in infarcted brain, i.e., target delivery using polymer, could modify the microenvironment to increase innate neurorestorative processes [25].

\section{CONCLUSION}

A number of biomarkers are under investigation in patients with ischemic stroke. Currently, however, application of biomarkers is only recommended for research purpose. Monitoring traditional risk factors or vessel status is more efficacious than measuring biomarkers in clinical practice. Considering advantages and disadvantages of each biomarker is important for future study, and comprehensive approach using multiple biomarkers is needed.

The role of biomarker is changing (Fig. 2). It is strongly expected that the biomarkers give us a turning point for investigating pathophysiology and therapeutic mechanisms of ischemic stroke. Continuous efforts are needed to find new biomarker and screening candidates for innate bio-makers

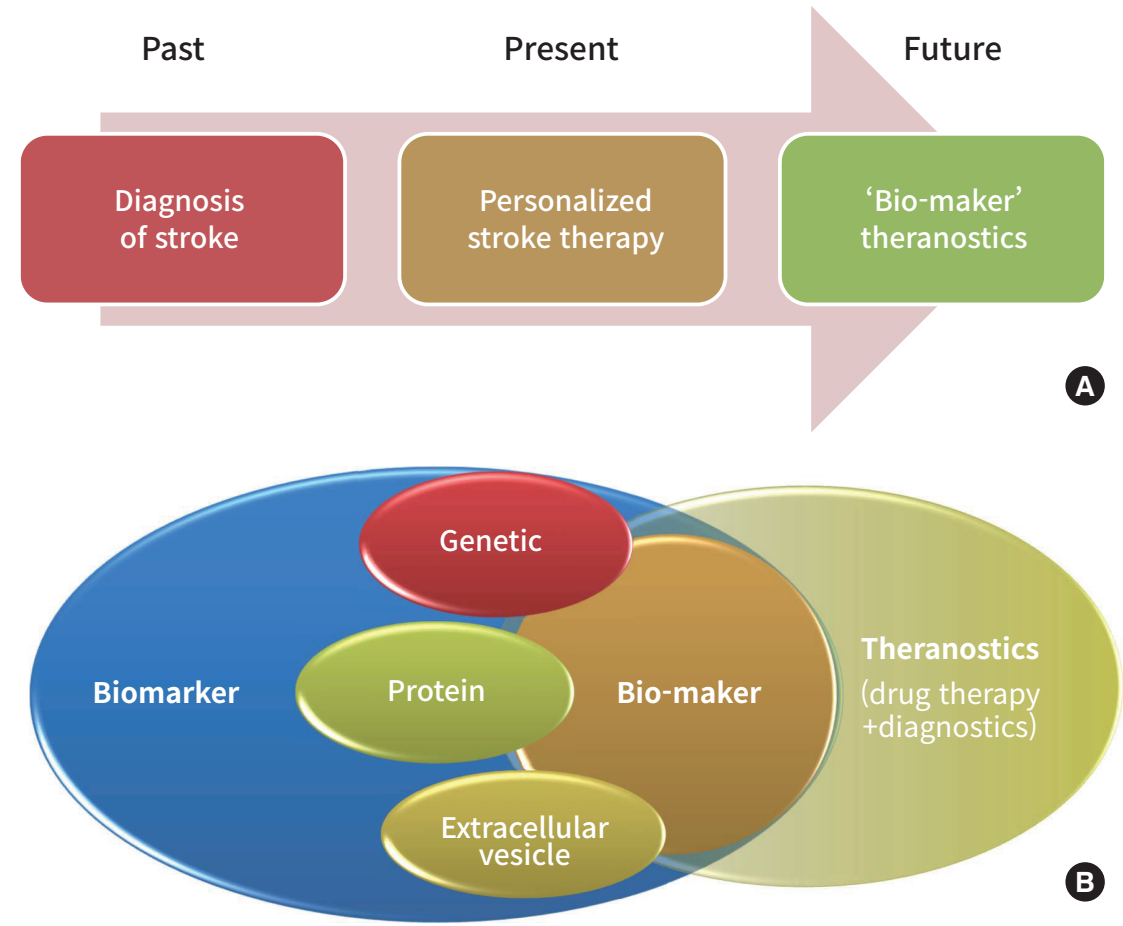

Fig. 2. Overview of biomarkers of stroke. (A) Changes in the role of biomarkers in stroke, (B) biomarker, bio-maker, and theranostics. 
among these biomarkers is important for the development of new therapeutic strategy in stroke

\section{CONFLICTS OF INTEREST}

No potential conflict of interest relevant to this article was reported.

\section{ORCID}

Oh Young Bang http://orcid.org/0000-0002-7962-8751

\section{REFERENCES}

1. Casper ML, Wing S, Anda RF, Knowles M, Pollard RA. The shifting stroke belt. Changes in the geographic pattern of stroke mortality in the United States, 1962 to 1988. Stroke 1995;26:755-60.

2. El-Saed A, Kuller LH, Newman AB, Lopez O, Costantino J, McTigue K, et al. Geographic variations in stroke incidence and mortality among older populations in four US communities. Stroke 2006;37:1975-9.

3. Howard G, Prineas R, Moy C, Cushman M, Kellum M, Temple $\mathrm{E}$, et al. Racial and geographic differences in awareness, treatment, and control of hypertension: the REasons for Geographic And Racial Differences in Stroke study. Stroke 2006;37:1171-8.

4. Bang OY, Ovbiagele B, Kim JS. Nontraditional risk factors for ischemic stroke: an update. Stroke 2015;46:3571-8.

5. Ridker PM, Brown NJ, Vaughan DE, Harrison DG, Mehta JL. Established and emerging plasma biomarkers in the prediction of first atherothrombotic events. Circulation 2004;109(25 Suppl 1):IV6-19.

6. Woodward M, Lowe GD, Campbell DJ, Colman S, Rumley $\mathrm{A}$, Chalmers J, et al. Associations of inflammatory and hemostatic variables with the risk of recurrent stroke. Stroke 2005;36:2143-7.

7. Ridker PM, Danielson E, Fonseca FA, Genest J, Gotto AM $\mathrm{Jr}$, Kastelein JJ, et al. Rosuvastatin to prevent vascular events in men and women with elevated C-reactive protein. $\mathrm{N}$ Engl J Med 2008;359:2195-207.

8. Welsh P, Lowe GD, Chalmers J, Campbell DJ, Rumley A, Neal BC, et al. Associations of proinflammatory cytokines with the risk of recurrent stroke. Stroke 2008;39:2226-30.

9. Pikula A, Boger RH, Beiser AS, Maas R, DeCarli C, Schwedhelm E, et al. Association of plasma ADMA levels with MRI markers of vascular brain injury: Framingham offspring study. Stroke 2009;40:2959-64.

10. Park CS, Ihm SH, Yoo KD, Kim DB, Lee JM, Kim HY, et al. Relation between C-reactive protein, homocysteine levels, fibrinogen, and lipoprotein levels and leukocyte and platelet counts, and 10-year risk for cardiovascular disease among healthy adults in the USA. Am J Cardiol 2010; 105:1284-8.

11. Wieberdink RG, van Schie MC, Koudstaal PJ, Hofman A, Witteman JC, de Maat MP, et al. High von Willebrand factor levels increase the risk of stroke: the Rotterdam study. Stroke 2010;41:2151-6.

12. Pikula A, Beiser AS, DeCarli C, Himali JJ, Debette S, Au R, et al. Multiple biomarkers and risk of clinical and subclinical vascular brain injury: the Framingham Offspring Study. Circulation 2012;125:2100-7.

13. Bang OY, Chung JW, Ryoo S, Moon GJ, Kim GM, Chung CS, et al. Brain microangiopathy and macroangiopathy share common risk factors and biomarkers. Atherosclerosis 2016; 246:71-7.

14. Yamada Y, Fuku N, Tanaka M, Aoyagi Y, Sawabe M, Metoki $\mathrm{N}$, et al. Identification of CELSR1 as a susceptibility gene for ischemic stroke in Japanese individuals by a genomewide association study. Atherosclerosis 2009;207:144-9.

15. Laskowitz DT, Kasner SE, Saver J, Remmel KS, Jauch EC; BRAIN Study Group. Clinical usefulness of a biomarkerbased diagnostic test for acute stroke: the Biomarker Rapid Assessment in Ischemic Injury (BRAIN) study. Stroke 2009;40:77-85.

16. Rodriguez-Yanez M, Sobrino T, Arias S, Vazquez-Herrero F, Brea D, Blanco M, et al. Early biomarkers of clinical-diffusion mismatch in acute ischemic stroke. Stroke 2011;42: 2813-8.

17. Kernagis DN, Laskowitz DT. Evolving role of biomarkers in acute cerebrovascular disease. Ann Neurol 2012;71:289303.

18. Kalow W, Tang BK, Endrenyi L. Hypothesis: comparisons of inter- and intra-individual variations can substitute for twin studies in drug research. Pharmacogenetics 1998; 8:283-9.

19. Higashi MK, Veenstra DL, Kondo LM, Wittkowsky AK, Srinouanprachanh SL, Farin FM, et al. Association between CYP2C9 genetic variants and anticoagulation-related outcomes dur ing warfarin therapy. JAMA 2002;287:1690-8.

20. Sconce EA, Khan TI, Wynne HA, Avery P, Monkhouse L, King BP, et al. The impact of CYP2C9 and VKORC1 genetic polymorphism and patient characteristics upon warfarin dose requirements: proposal for a new dosing regimen. 
Blood 2005;106:2329-33.

21. Heo JH, Kim SH, Lee KY, Kim EH, Chu CK, Nam JM. Increase in plasma matrix metalloproteinase- 9 in acute stroke patients with thrombolysis failure. Stroke 2003;34:e48-50.

22. Montaner J, Molina CA, Monasterio J, Abilleira S, Arenillas JF, Ribo M, et al. Matrix metalloproteinase-9 pretreatment level predicts intracranial hemorrhagic complications after thrombolysis in human stroke. Circulation 2003;107: 598-603.

23. Foerch C, Wunderlich MT, Dvorak F, Humpich M, Kahles T, Goertler M, et al. Elevated serum S100B levels indicate a higher risk of hemorrhagic transformation after thrombolytic therapy in acute stroke. Stroke 2007;38:2491-5.

24. Marti-Fabregas J, Borrell M, Cocho D, Belvis R, Castellanos $\mathrm{M}$, Montaner J, et al. Hemostatic markers of recanalization in patients with ischemic stroke treated with rt-PA. Neurology 2005;65:366-70.

25. Kim DH, Seo YK, Thambi T, Moon GJ, Son JP, Li G, et al. Enhancing neurogenesis and angiogenesis with target delivery of stromal cell derived factor-1alpha using a dual ionic pH-sensitive copolymer. Biomaterials 2015;61:11525.

26. Reynolds MA, Kirchick HJ, Dahlen JR, Anderberg JM, McPherson PH, Nakamura KK, et al. Early biomarkers of stroke. Clin Chem 2003;49:1733-9.

27. Jauch EC, Lindsell C, Broderick J, Fagan SC, Tilley BC, Levine SR, et al. Association of serial biochemical markers with acute ischemic stroke: the National Institute of Neurological Disorders and Stroke recombinant tissue plasminogen activator Stroke Study. Stroke 2006;37:2508-13.

28. Montaner J, Rovira A, Molina CA, Arenillas JF, Ribo M, Chacon $P$, et al. Plasmatic level of neuroinflammatory markers predict the extent of diffusion-weighted image lesions in hyperacute stroke. J Cereb Blood Flow Metab 2003;23: 1403-7.

29. Bang OY, Lee PH, Yoon SR, Lee MA, Joo IS, Huh K. Inflammatory markers, rather than conventional risk factors, are different between carotid and MCA atherosclerosis. J Neurol Neurosurg Psychiatry 2005;76:1128-34.

30. Iwamoto T, Kubo H, Takasaki M. Platelet activation in the cerebral circulation in different subtypes of ischemic stroke and Binswanger's disease. Stroke 1995;26:52-6.

31. Hanson E, Jood K, Karlsson S, Nilsson S, Blomstrand C, Jern C. Plasma levels of von Willebrand factor in the etiologic subtypes of ischemic stroke. J Thromb Haemost 2011;9:275-81.

32. Choi JY, Jung JM, Kwon DY, Park MH, Kim JH, Oh K, et al.
Free fatty acid as an outcome predictor of atrial fibrillationassociated stroke. Ann Neurol 2016;79:317-25.

33. Seok JM, Kim SG, Kim JW, Chung CS, Kim GM, Lee KH, et al. Coagulopathy and embolic signal in cancer patients with ischemic stroke. Ann Neurol 2010;68:213-9.

34. Matsui T, Mori T, Tateishi N, Kagamiishi Y, Satoh S, Katsube $\mathrm{N}$, et al. Astrocytic activation and delayed infarct expansion after permanent focal ischemia in rats. Part I: enhanced astrocytic synthesis of s-100beta in the periinfarct area precedes delayed infarct expansion. J Cereb Blood Flow Metab 2002;22:711-22.

35. Foerch C, du Mesnil de Rochemont R, Singer O, NeumannHaefelin T, Buchkremer M, Zanella FE, et al. S100B as a surrogate marker for successful clot lysis in hyperacute middle cerebral artery occlusion. J Neurol Neurosurg Psychiatry 2003;74:322-5.

36. Vila N, Castillo J, Davalos A, Chamorro A. Proinflammatory cytokines and early neurological worsening in ischemic stroke. Stroke 2000;31:2325-9.

37. Whiteley W, Jackson C, Lewis S, Lowe G, Rumley A, Sandercock P, et al. Inflammatory markers and poor outcome after stroke: a prospective cohort study and systematic review of interleukin-6. PLoS Med 2009;6:e1000145.

38. Kang DW, Yoo SH, Chun S, Kwon KY, Kwon SU, Koh JY, et al. Inflammatory and hemostatic biomarkers associated with early recurrent ischemic lesions in acute ischemic stroke. Stroke 2009;40:1653-8.

39. Motoki H, Tomita T, Aizawa K, Kasai H, Izawa A, Kumazaki $S$, et al. Coagulation activity is increased in the left atria of patients with paroxysmal atrial fibrillation during the non- paroxysmal period. Comparison with chronic atrial fibrillation. Circ J 2009;73:1403-7.

40. Roldan V, Marin F, Muina B, Torregrosa JM, HernandezRomero D, Valdes M, et al. Plasma von Willebrand factor levels are an independent risk factor for adverse events including mortality and major bleeding in anticoagulated atrial fibrillation patients. J Am Coll Cardiol 2011;57: 2496-504.

41. Conway DS, Pearce LA, Chin BS, Hart RG, Lip GY. Prognostic value of plasma von Willebrand factor and soluble P-selectin as indices of endothelial damage and platelet activation in 994 patients with nonvalvular atrial fibrillation. Circulation 2003;107:3141-5.

42. Rost NS, Biffi A, Cloonan L, Chorba J, Kelly P, Greer D, et al. Brain natriuretic peptide predicts functional outcome in ischemic stroke. Stroke 2012;43:441-5.

43. Cheeran B, Talelli P, Mori F, Koch G, Suppa A, Edwards M, 
et al. A common polymorphism in the brain-derived neurotrophic factor gene (BDNF) modulates human cortical plasticity and the response to rTMS. J Physiol 2008;586: 5717-25.

44. Siironen J, Juvela S, Kanarek K, Vilkki J, Hernesniemi J, Lappalainen J. The Met allele of the BDNF Val66Met polymorphism predicts poor outcome among survivors of aneurysmal subarachnoid hemorrhage. Stroke 2007;38: 2858-60.

45. Halim SA, Newby LK, Ohman EM. Biomarkers in cardiovascular clinical trials: past, present, future. Clin Chem 2012;58:45-53.

46. Nozaki T, Sugiyama S, Koga H, Sugamura K, Ohba K, Matsuzawa $Y$, et al. Significance of a multiple biomarkers strategy including endothelial dysfunction to improve risk stratification for cardiovascular events in patients at high risk for coronary heart disease. J Am Coll Cardiol 2009;54:601-8.

47. Lynch JR, Blessing R, White WD, Grocott HP, Newman MF, Laskowitz DT. Novel diagnostic test for acute stroke. Stroke 2004;35:57-63.

48. Ridker PM, Cushman M, Stampfer MJ, Tracy RP, Hennekens $\mathrm{CH}$. Inflammation, aspirin, and the risk of cardiovascular disease in apparently healthy men. N Engl J Med 1997;336:973-9.

49. Van Der Meer IM, De Maat MP, Hak AE, Kiliaan AJ, Del Sol Al, Van Der Kuip DA, et al. C-reactive protein predicts progression of atherosclerosis measured at various sites in the arterial tree: the Rotterdam Study. Stroke 2002;33: 2750-5.

50. Hemingway H, Philipson P, Chen R, Fitzpatrick NK, Damant J, Shipley M, et al. Evaluating the quality of research into a single prognostic biomarker: a systematic review and meta-analysis of 83 studies of C-reactive protein in stable coronary artery disease. PLoS Med 2010;7:e1000286.

51. Hankey GJ. Potential new risk factors for ischemic stroke: what is their potential? Stroke 2006;37:2181-8.

52. O'Donnell MJ, Xavier D, Liu L, Zhang H, Chin SL, Rao-Melacini $P$, et al. Risk factors for ischaemic and intracerebral haemorrhagic stroke in 22 countries (the INTERSTROKE study): a case-control study. Lancet 2010;376:112-23.

53. Dichgans M. Genetics of ischaemic stroke. Lancet Neurol 2007;6:149-61.

54. Lanktree MB, Dichgans M, Hegele RA. Advances in genomic analysis of stroke: what have we learned and where are we headed? Stroke 2010;41:825-32.

55. Ikram MA, Seshadri S, Bis JC, Fornage M, DeStefano AL, Aulchenko YS, et al. Genomewide association studies of stroke. N Engl J Med 2009;360:1718-28.

56. Traylor M, Farrall M, Holliday EG, Sudlow C, Hopewell JC, Cheng YC, et al. Genetic risk factors for ischaemic stroke and its subtypes (the METASTROKE collaboration): a meta-analysis of genome-wide association studies. Lancet Neurol 2012;11:951-62.

57. Achterberg S, Kappelle LJ, de Bakker PI, Traylor M, Algra A; SMART Study Group and the METASTROKE Consortium, et al. No additional prognostic value of genetic information in the prediction of vascular events after cerebral ischemia of arterial origin: the PROMISe study. PLoS One 2015;10:e0119203.

58. Kim CK, Kim T, Choi IY, Soh M, Kim D, Kim YJ, et al. Ceria nanoparticles that can protect against ischemic stroke. Angew Chem Int Ed Engl 2012;51:11039-43.

59. Agulla J, Brea D, Campos F, Sobrino T, Argibay B, Al-Soufi $W$, et al. In vivo theranostics at the peri-infarct region in cerebral ischemia. Theranostics 2013;4:90-105.

60. Kim JY, Ryu JH, Schellingerhout D, Sun IC, Lee SK, Jeon S, et al. Direct imaging of cerebral thromboemboli using computed tomography and fibrin-targeted gold nanoparticles. Theranostics 2015;5:1098-114.

61. Belayev L, Saul I, Huh PW, Finotti N, Zhao W, Busto R, et al. Neuroprotective effect of high-dose albumin therapy against global ischemic brain injury in rats. Brain Res 1999; 845:107-11.

62. Hong JM, Bang OY, Chung CS, Joo IS, Gwag BJ, Ovbiagele B. Influence of recanalization on uric acid patterns in acute ischemic stroke. Cerebrovasc Dis 2010;29:431-9.

63. Pineda S, Bang OY, Saver JL, Starkman S, Yun SW, Liebeskind DS, et al. Association of serum bilirubin with ischemic stroke outcomes. J Stroke Cerebrovasc Dis 2008;17:14752.

64. Kimm H, Yun JE, Jo J, Jee SH. Low serum bilirubin level as an independent predictor of stroke incidence: a prospective study in Korean men and women. Stroke 2009; 40:3422-7.

65. Perlstein TS, Pande RL, Creager MA, Weuve J, Beckman JA. Serum total bilirubin level, prevalent stroke, and stroke outcomes: NHANES 1999-2004. Am J Med 2008;121:7818.e1.

66. Shin DH, Moon GJ, Bang OY. Albumin therapy in acute stroke patients. J Neurol 2007;254:870-8.

67. Ginsberg MD, Palesch YY, Hill MD, Martin RH, Moy CS, Barsan WG, et al. High-dose albumin treatment for acute ischaemic stroke (ALIAS) Part 2: a randomised, double-blind, phase 3, placebo-controlled trial. Lancet Neurol 2013;12: 
1049-58.

68. Chamorro A, Amaro S, Castellanos M, Segura T, Arenillas J, Marti-Fabregas J, et al. Safety and efficacy of uric acid in patients with acute stroke (URICO-ICTUS): a randomised, double-blind phase 2b/3 trial. Lancet Neurol 2014;13:45360.

69. Llull L, Laredo C, Renu A, Perez B, Vila E, Obach V, et al. Uric acid therapy improves clinical outcome in women with acute ischemic stroke. Stroke 2015;46:2162-7.

70. Amaro S, Llull L, Renu A, Laredo C, Perez B, Vila E, et al. Uric acid improves glucose-driven oxidative stress in human ischemic stroke. Ann Neurol 2015;77:775-83.

71. Chen X, Ba Y, Ma L, Cai X, Yin Y, Wang K, et al. Characterization of microRNAs in serum: a novel class of biomarkers for diagnosis of cancer and other diseases. Cell Res 2008; 18:997-1006.

72. Zhao H, Wang J, Gao L, Wang R, Liu X, Gao Z, et al. MiRNA-424 protects against permanent focal cerebral ischemia injury in mice involving suppressing microglia activation. Stroke 2013;44:1706-13.

73. Sepramaniam S, Tan JR, Tan KS, DeSilva DA, Tavintharan $\mathrm{S}$, Woon FP, et al. Circulating microRNAs as biomarkers of acute stroke. Int J Mol Sci 2014;15:1418-32.

74. Stary CM, Xu L, Sun X, Ouyang YB, White RE, Leong J, et al. MicroRNA-200c contributes to injury from transient focal cerebral ischemia by targeting Reelin. Stroke 2015; 46:551-6.

75. van Rooij E, Olson EN. MicroRNA therapeutics for cardiovascular disease: opportunities and obstacles. Nat Rev Drug Discov 2012;11:860-72.

76. Kim SJ, Moon GJ, Cho YH, Kang HY, Hyung NK, Kim D, et al. Circulating mesenchymal stem cells microparticles in patients with cerebrovascular disease. PLoS One 2012;7: e37036.

77. Leroyer AS, Ebrahimian TG, Cochain C, Recalde A, BlancBrude $\mathrm{O}$, Mees B, et al. Microparticles from ischemic muscle promotes postnatal vasculogenesis. Circulation 2009; 119:2808-17.

78. Raisi A, Azizi S, Delirezh N, Heshmatian B, Farshid AA, Ami- ni K. The mesenchymal stem cell-derived microvesicles enhance sciatic nerve regeneration in rat: a novel approach in peripheral nerve cell therapy. J Trauma Acute Care Surg 2014;76:991-7.

79. Taylor AR, Robinson MB, Gifondorwa DJ, Tytell M, Milligan CE. Regulation of heat shock protein 70 release in astrocytes: role of signaling kinases. Dev Neurobiol 2007;67: 1815-29.

80. Xin H, Li Y, Cui Y, Yang JJ, Zhang ZG, Chopp M. Systemic administration of exosomes released from mesenchymal stromal cells promote functional recovery and neurovascular plasticity after stroke in rats. J Cereb Blood Flow Metab 2013;33:1711-5.

81. Moon GJ, Sung JH, Kim DH, Cho YH, Band OY. Mesenchymal stem cell-derived microvesicle therapy for stroke: neurogenic/angiogenic effects and biodistribution in a rat stroke model. Abstracts from the Fourth International Meeting of ISEV, ISEV2015, Washington, D.C., USA, 23-26 April 2015. J Extracell Vesicles 2015;4(Suppl 1):27783.

82. Frank PG, Woodman SE, Park DS, Lisanti MP. Caveolin, caveolae, and endothelial cell function. Arterioscler Thromb Vasc Biol 2003;23:1161-8.

83. Bang OY, Chung JW, Kim SJ, Oh MJ, Kim SY, Cho YH, et al. Caveolin-1, Ring finger protein 213, and endothelial function in Moyamoya disease. Int J Stroke 2016;11:999-1008.

84. Sonveaux P, Martinive P, DeWever J, Batova Z, Daneau G, Pelat M, et al. Caveolin-1 expression is critical for vascular endothelial growth factor-induced ischemic hindlimb collateralization and nitric oxide-mediated angiogenesis. Circ Res 2004;95:154-61.

85. Sbaa E, Dewever J, Martinive P, Bouzin C, Frerart F, Balligand JL, et al. Caveolin plays a central role in endothelial progenitor cell mobilization and homing in SDF-1-driven postischemic vasculogenesis. Circ Res 2006;98:1219-27.

86. Lee JS, Hong JM, Moon GJ, Lee PH, Ahn YH, Bang OY, et al. A long-term follow-up study of intravenous autologous mesenchymal stem cell transplantation in patients with ischemic stroke. Stem Cells 2010;28:1099-106. 